\title{
Effects of abomasal infusion of conjugated linoleic acids, Sterculia foetida oil, and fish oil on production performance and the extent of fatty acid $\Delta^{9}$-desaturation in dairy cows
}

\author{
M. P. Dallaire, ${ }^{*} \dagger$ H. Taga, ${ }^{*}$ L. Ma, $\ddagger$ B. A. Corl, $\ddagger$ R. Gervais, ${ }^{*}$ Y. Lebeuf, ${ }^{*} \dagger$ F. J. Richard, ${ }^{\star} \S$ and P. Y. Chouinard ${ }^{*} \dagger^{1}$ \\ *Département des Sciences Animales, Université Laval, Québec, QC, G1V 0A6 Canada \\ †Institute of Nutrition and Functional Foods, Québec, QC, G1V 0A6 Canada \\ ‡Department of Dairy Science, Virginia Tech, Blacksburg 24061 \\ §Centre de Recherche en Biologie de la Reproduction, Université Laval, Québec, QC, G1V 0A6 Canada
}

\begin{abstract}
The purpose of this study was to determine the effects of conjugated linoleic acid (CLA), Sterculia foetida oil (STO), and fish oil (FO) on milk yield and composition, milk FA profile, $\Delta^{9}$-desaturation activity, and mammary expression of 2 isoforms of stearoyl-coenzyme A desaturase $(S C D-1$ and $S C D-5)$ in lactating dairy cows. Eight multiparous Holstein cows $(69 \pm 13 \mathrm{~d}$ postpartum) were used in a double $4 \times 4$ Latin square design with 28 -d periods. For the first $14 \mathrm{~d}$ of each period, cows received an abomasal infusion of (1) $406 \mathrm{~g}$ of a saturated fatty acid (SFA) supplement (112 g of 16:0 $+230 \mathrm{~g}$ of 18:0) used as a control (CTL), (2) $36 \mathrm{~g}$ of a CLA supplement (13.9 g of trans-10, cis-12 18:2) + 370 $\mathrm{g}$ of SFA, (3) $7 \mathrm{~g}$ of STO (3.1 g of 19:1 cyclo) $+399 \mathrm{~g}$ of SFA, or (4) $406 \mathrm{~g}$ of FO (55.2 $\mathrm{g}$ of cis-5,-8,-11,-14,-17 $20: 5+59.3 \mathrm{~g}$ of cis-4,-7,-10,-13,-16,-19 22:6). Infusions were followed by a 14-d washout interval. Compared with CTL, STO decreased milk yield from 38.0 to 33.0 $\mathrm{kg} / \mathrm{d}$, and increased milk fat concentration from 3.79 to $4.45 \%$. Milk fat concentration was also decreased by CLA $(2.23 \%)$ and FO (3.34\%). Milk fat yield was not affected by STO $(1,475 \mathrm{~g} / \mathrm{d})$ compared with CTL $(1,431 \mathrm{~g} / \mathrm{d})$, but was decreased by CLA $(774 \mathrm{~g} / \mathrm{d})$ and FO $(1,186 \mathrm{~g} / \mathrm{d})$. Desaturase indices for 10:0, 12:0, and 20:0 were decreased, whereas the extent of desaturation of 14:0, 16:0, 17:0, and 18:0 was not affected by CLA treatment compared with CTL. Infusion of STO significantly decreased all calculated desaturase indices compared with CTL; the 14:0 index was reduced by $80.7 \%$. Infusion of FO decreased the desaturase indices for 10:0, 14:0, 20:0, trans-11 18:1, and 18:0. The effect of $\mathrm{FO}$ on the 14:0 index indicates a decrease in apparent $\Delta^{9}$-desaturase activity of $30.2 \%$. Compared
\end{abstract}

Received December 18, 2013.

Accepted June 7, 2014.

${ }^{1}$ Corresponding author: yvan.chouinard@fsaa.ulaval.ca with CTL, mammary mRNA abundance of $S C D-1$ was increased by STO $(+30 \%)$ and decreased by CLA $(-24 \%)$, whereas FO had no effect. No effect was observed on mRNA abundance of $S C D$-5. In conclusion, abomasal infusion of CLA, STO, and FO were shown to exhibit varying and distinct effects on desaturase indices, an indicator of apparent SCD activity, and mammary mRNA abundance of $S C D-1$.

Key words: conjugated linoleic acid, sterculic acid, long-chain n-3 fatty acid, stearoyl-coenzyme A desaturase

\section{INTRODUCTION}

In dairy cows, dietary lipids are extensively hydrogenated by rumen microorganisms (Doreau and Ferlay, 1994). In this regard, a meta-analysis by Glasser et al. (2008) has shown that 62,67 , and $40 \%$ of dietary $18: 1$, $18: 2$, and 18:3, respectively, leaves the rumen as 18:0. As a consequence, 18:0 is the predominant FA reaching the duodenum, and available for uptake by the mammary gland for milk fat synthesis. Milk triglycerides must be composed of a combination of FA with a fluidity that allows secretion by mammary cells (Chilliard et al., 2000; Toral et al., 2013). Acylation of cis-9 18:1 in the $s n-3$ position of milk triglycerides has been proposed as one of the regulation mechanisms to maintain dairy fat plasticity (Hawke and Taylor, 1983). In the mammary tissue of dairy cows, $\Delta^{9}$-desaturase activity regulates the availability of cis-9 $18: 1$ by adding a cis double bond on the ninth carbon of the saturated chain of 18:0 (Cook et al., 1976). Similarly, $\Delta^{9}$-desaturase can also introduce a cis-9 double bond on many saturated or unsaturated short-, medium-, and long-chain FA (Ntambi and Miyazaki, 2004). The enzyme $\Delta^{9}$-desaturase [stearoyl-CoA desaturase (SCD)] is encoded by multiple genes. Four $S C D$ isoforms have been identified in rodents (Bernard et al. 2013). In ruminants, $S C D-1$ is the primary isoform of the enzyme, and was the only one identified until Lengi and Corl (2007) character- 
ized a new $S C D-5$ isoform. Both $S C D-1$ and $S C D-5$ are expressed in bovine mammary tissue (Gervais et al., 2009; Jacobs et al., 2011), with $S C D-1$ mRNA being substantially more abundant than $S C D-5$ (Jacobs et al., 2011, 2013).

Several hormonal and dietary factors were reported to modulate $S C D-1$ gene expression (Mauvoisin and Mounier, 2011). In lactating ruminants, trans-10, cis-12 18:2, a CLA isomer, has been shown to reduce relative mRNA abundance of the $S C D-1$ gene (Baumgard et al., 2002; Gervais et al. 2009; Hussein et al., 2013a). Studies of the effect of reduced $S C D$-1 gene transcription on FA desaturation, as assessed by the calculation of milk FA product-to-substrate ratio, has shown inconsistent results, with a reduction (Baumgard et al., 2002) or no effect (Gervais et al., 2009) on apparent enzyme activity in dairy cows.

Sterculic acid [8-(2-octyl-1-cyclopropenyl)octanoic acid, or 19:1 cyclo], a cyclopropene FA found in Sterculia foetida oil (STO) has also been studied for its inhibiting effect on FA $\Delta^{9}$-desaturation and the resulting effect on milk FA profile in lactating dairy cows (Griinari et al., 2000; Corl et al., 2001; Kay et al., 2004). In those trials, STO drastically reduced the apparent desaturase activity when abomasally infused during experimental periods of $4 \mathrm{~d}$. However, the longer-term effects of STO on milk FA profile and its effect on lactating bovine mammary $S C D$ gene expression remain to be established.

Long-chain PUFA (e.g., cis-5,-8,-11,-14,-17 20:5 and cis-4,-7,-10,-13,-16,-19 22:6) found in fish oil (FO) are known to inhibit $S C D-1$ gene expression in various experimental models (Mauvoisin and Mounier, 2011). In dairy cows, Chilliard et al. (2001) reported a decrease in milk cis 18:1-to-18:0 ratio after duodenal FO infusion, which was tentatively explained by the inhibitory effect of long-chain PUFA on $\Delta^{9}$-desaturase gene expression. This mechanism was further confirmed by Ahnadi et al. (2002), who observed a decrease in $S C D-1$ mRNA abundance when feeding protected FO. However, in trials conducted to evaluate the postruminal supply of cis-5,-8,-11,-14,-17 20:5 and cis-4,-7,-10,-13,-16,-19 22:6 using either dietary protected FO (Ahnadi et al., 2002) or duodenal FO infusion (Loor et al., 2005), the comparison was made with a control treatment where no fat was added. Consequently, a need exists to evaluate the effect of FO on animal performance and $\Delta^{9}$-desaturase activity using isolipidic supplementation to equilibrate dietary energy supply between treatments. The objective of the current experiment was to evaluate the effect of postruminal supply of CLA, STO, and FO on lactation performance, milk FA profile, and $\Delta^{9}$-desaturation in lactating dairy cows.

\section{MATERIALS AND METHODS}

\section{Cows, Feeding, and Treatments}

All procedures involving animals were conducted according to the regulations of the Canadian Council on Animal Care (CCAC, 1993), and were approved by the Université Laval animal care committee (Québec, QC, Canada). Eight multiparous Holstein cows (BW: 635 $\pm 34 \mathrm{~kg})$ in early lactation $(69 \pm 13 \mathrm{~d}$ postpartum), and fitted with rumen cannulas were housed in a tiestall facility at the Centre de Recherche en Sciences Animales de Deschambault (Portneuf, QC, Canada). Cows received a TMR (Table 1) formulated to meet or exceed predicted nutrient requirements (NRC, 2001). Animals had access to water at all times and were fed once daily after the morning milking. Samples of silages composing the TMR were taken each week and oven dried at $55^{\circ} \mathrm{C}$ for $48 \mathrm{~h}$ to adjust the proportions of feed ingredients. Orts were weighed daily just before feeding, and the amount of feed offered was adjusted to allow $10 \%$ refusal.

Cows were abomasally infused with lipid emulsions according to a double $4 \times 4$ Latin square design with 28 -d periods. For the first $14 \mathrm{~d}$ of each period, cows received abomasal infusion of (1) $406 \mathrm{~g}$ of an SFA supplement [Energy Booster 100 (EB; Milk Specialties Global, Eden Prairie, MN], used as the control (CTL); (2) $36 \mathrm{~g}$ of a CLA supplement [Tonalin; Cognis Canada Corp., Mississauga, ON, Canada] +370 g of EB; (3) $7 \mathrm{~g}$ of STO + $399 \mathrm{~g}$ of EB; and (4) $406 \mathrm{~g}$ of FO [Virginia Prime Gold Menhaden Oil; Omega Protein Inc., Houston, TX]. The composition of each FA supplement is presented in Table 2. To minimize carryover effects, infusion periods were separated by a 14-d washout interval.

\section{Preparation of Emulsions and Infusion Procedure}

The ingredient composition of experimental emulsions is presented in Table 3. Emulsions were prepared following the procedure described by Drackley et al. (1992), with modifications. First, whey protein concentrate (AMP 80; American Meat Protein Corp., Boone, IA) was dispersed in tap water using a Scanima mixer (model SRB-25; Tetra Pak Scanima A/S, Aalborg, Denmark) at minimum speed. For treatments CTL, STO, and CLA, the mixture (AMP 80 in water) was heated at $70^{\circ} \mathrm{C}$, whereas EB was melted separately until also reaching $70^{\circ} \mathrm{C}$. The appropriate amount of melted EB was then added to the mixture of AMP 80 in water, along with Tween 80 (Fisher Scientific, Fair Lawn, NJ) and CLA or STO, depending on treatment. The mixture was stirred at maximum speed for $10 \mathrm{~min}$. 
Table 1. Ingredients and chemical composition of TMR

\begin{tabular}{|c|c|}
\hline Item & Amount \\
\hline \multicolumn{2}{|l|}{ Ingredient ( $\%, \mathrm{DM}$ basis $)$} \\
\hline Grass and legume silage & 30.3 \\
\hline Corn silage & 18.3 \\
\hline Grass hay & 5.8 \\
\hline Cracked corn & 21.8 \\
\hline Rolled barley & 7.4 \\
\hline Soybean meal & 7.7 \\
\hline Corn gluten meal & 5.6 \\
\hline Calcium carbonate & 0.8 \\
\hline Sodium bicarbonate & 0.7 \\
\hline Iodized salt & 0.2 \\
\hline Magnesium oxide & 0.1 \\
\hline Vitamin and mineral mix ${ }^{1}$ & 0.9 \\
\hline \multicolumn{2}{|l|}{ Chemical composition } \\
\hline $\mathrm{DM}(\%$ as fed $)$ & 49.3 \\
\hline $\mathrm{OM}(\%$ of $\mathrm{DM})$ & 93.9 \\
\hline $\mathrm{CP}(\%$ of $\mathrm{DM})$ & 15.4 \\
\hline NDF ( $\%$ of DM) & 32.3 \\
\hline $\mathrm{ADF}(\%$ of $\mathrm{DM})$ & 19.7 \\
\hline Ether extract (\% of DM) & 3.5 \\
\hline \multicolumn{2}{|l|}{$\mathrm{FA}(\mathrm{mg} / \mathrm{g}$ of $\mathrm{DM})$} \\
\hline $14: 0$ & 0.1 \\
\hline $16: 0$ & 3.8 \\
\hline cis-9 16:1 & 0.1 \\
\hline 18:0 & 0.5 \\
\hline cis-9 18:1 & 4.4 \\
\hline cis-11 18:1 & 0.2 \\
\hline cis-9,-12 18:2 & 11.1 \\
\hline cis- $9,-12,-15 \quad 18: 3$ & 2.5 \\
\hline $20: 0$ & 0.1 \\
\hline Total & 22.7 \\
\hline $\mathrm{NE}_{\mathrm{L}}^{2}(\mathrm{Mcal} / \mathrm{kg}$ of $\mathrm{DM})$ & 1.67 \\
\hline
\end{tabular}

${ }^{1}$ Contained $3 \% \mathrm{Ca}, 13 \% \mathrm{P}, 10 \% \mathrm{Na}, 5 \% \mathrm{Mg}, 40 \mathrm{mg}$ of $\mathrm{Co} / \mathrm{kg}, 7,775 \mathrm{mg}$ of $\mathrm{Fe} / \mathrm{kg}, 3,100 \mathrm{mg}$ of $\mathrm{Mn} / \mathrm{kg}, 3,640 \mathrm{mg}$ of $\mathrm{Zn} / \mathrm{kg}$, $890 \mathrm{mg}$ of $\mathrm{Cu} / \mathrm{kg}$, $80 \mathrm{mg}$ of I/ kg, $31 \mathrm{mg}$ of Se/ kg, $350 \mathrm{kIU}$ of vitamin A/kg, $150 \mathrm{kIU}$ of vitamin $\mathrm{D} / \mathrm{kg}$, and $1,550 \mathrm{IU}$ of vitamin $\mathrm{E} / \mathrm{kg}$.

${ }^{2} \mathrm{NE}_{\mathrm{L}}$ calculated based on tabular values from NRC (2001).

To prepare the FO emulsion, the mixture of AMP 80 in water was heated at $35^{\circ} \mathrm{C}$. Fish oil and Tween 80 were then added before a 10-min blending with the Scanima mixer at maximum speed.

Each preparation was finally passed through a homogenizer (EmulsiFlex-C160; Avestin Inc., Ottawa, ON, Canada) with a pressure of $55,158 \mathrm{kPa}$, and the resulting emulsions were cooled to $30^{\circ} \mathrm{C}$ in an ice bath. This process produced a liquid for infusion in which the lipid remained uniformly dispersed. Emulsions were prepared weekly and were stored at $4^{\circ} \mathrm{C}$ until use. Emulsions were abomasally infused via Nalgene tubing (4.8mm i.d., 1.6-mm wall; Fisher Scientific, Ottawa, ON, Canada) that was passed through the rumen cannula, rumen compartments, and sulcus omasi, and placed into the abomasum as previously described (Gressley et al., 2006). Emulsions were continuously infused by means of a peristaltic pump (Masterflex; Cole-Parmer Instrument Co., Montréal, QC, Canada) at the rate of $5 \mathrm{~kg} / \mathrm{d}$. Cows were gradually adapted to abomasal infusions by receiving one-third, and two-thirds of total emulsion on d 1 and 2 of each 14-d period, respectively.

\section{Measurements, Sampling, and Analyses}

Cows were weighed after the a.m. milking on d 13 and 14 of each infusion period. The amounts of feed offered and refused were recorded, and samples of TMR were collected on d 12, 13, and 14 and pooled by period. A first aliquot was dried at $55^{\circ} \mathrm{C}$ for $48 \mathrm{~h}$ for DM concentration. A second aliquot was stored at $-20^{\circ} \mathrm{C}$ for further analyses by wet chemistry (Dairy One Laboratory, Ithaca, NY) according to the following methods: DM (method 2.2.1.1; National Forage Testing Association; Undersander et al., 1993), residual moisture (method 991.01; AOAC International, 2012), ash (method 942.05; AOAC International, 2012), ADF (Ankom Technology method 5: ADF in feeds-filter bag technique for A200; solutions as in method 973.18; AOAC International, 2012), NDF (Ankom Technology method 6: NDF in feeds - filter bag technique for A200; solutions as in Van Soest et al., 1991), and ether extract (method 2003.05; AOAC International, 2012). A third aliquot was used to determine the FA profile after freeze-drying and grinding through a 1-mm screen. Fatty acids were directly transesterified, and FAME were extracted and quantified by gas chromatography following the method described by Villeneuve et al. (2013).

Cows were milked twice daily at 0700 and $1700 \mathrm{~h}$, and yield was recorded at each milking. Samples of milk were taken on d 12, 13, and 14 of each infusion period. Samples from the p.m. milking were mixed with samples from the next a.m. milking, proportionately to milk yield. A first aliquot was stored at $4^{\circ} \mathrm{C}$, with bronopol as preservative, before being analyzed for fat. Milk composition analyses were conducted at the Québec Dairy Production Centre of Expertise (Valacta, Sainte-Anne-de-Bellevue, QC, Canada) using an infrared procedure with a Foss MilkoScan FT 6000 instrument (Foss Electric A/S, Hillerød, Denmark).

A second aliquot was stored at $-20^{\circ} \mathrm{C}$ without preservative for analysis of FA composition. Lipid extraction of milk samples was performed and the extracted lipids were methylated according to the method of Chouinard et al. (1997). Composition analyses of the FA were carried out with a gas chromatograph (7890A GC; Agilent Technologies Canada Inc., Mississauga, ON, Canada) equipped with a 100-m CP-Sil 88 capillary column (0.25-mm i.d., 0.20- $\mu \mathrm{m}$ film thickness; Agilent Technologies Canada Inc.) and a flame ionization detector according to the procedure described by Boivin et al. 
DALLAIRE ET AL.

Table 2. Fatty acid profile of experimental fat supplements

\begin{tabular}{|c|c|c|c|c|}
\hline \multirow[b]{2}{*}{$\begin{array}{l}\text { FA } \\
\text { (\% by weight) }\end{array}$} & \multicolumn{4}{|c|}{ Experimental fat supplement } \\
\hline & $\mathrm{SFA}^{1}$ & CLA $^{2}$ & $\begin{array}{c}\text { Sterculia } \\
\text { foetida oil }\end{array}$ & $\begin{array}{l}\text { Menhaden } \\
\text { fish oil }^{3}\end{array}$ \\
\hline 14:0 & 4.3 & -4 & 0.1 & 8.9 \\
\hline cis-9 14:1 & - & - & - & 0.1 \\
\hline $15: 0$ & 0.5 & - & - & 0.9 \\
\hline $16: 0$ & 27.6 & 1.1 & 19.8 & 19.0 \\
\hline trans-9 16:1 & 0.3 & - & - & - \\
\hline cis-9 16:1 & 0.8 & - & 0.2 & 11.4 \\
\hline $17: 0$ & 1.6 & - & - & 0.6 \\
\hline 18:0 & 56.6 & 2.7 & 3.8 & 3.3 \\
\hline cis-9 18:1 & 5.0 & 14.9 & 8.4 & 5.7 \\
\hline cis-11 18:1 & 0.2 & 0.8 & 0.8 & 3.0 \\
\hline cis-9,-12 18:2 & 0.5 & 0.2 & 7.2 & 1.5 \\
\hline $20: 0$ & 0.8 & 0.2 & 0.2 & 0.2 \\
\hline cis- $6,-9,-12 \quad 18: 3$ & - & - & - & 0.3 \\
\hline cis-9 20:1 & - & - & 0.1 & 0.5 \\
\hline cis-11 20:1 & - & - & 0.1 & 0.9 \\
\hline cis-9,-12,-15 18:3 & - & - & 0.2 & 1.7 \\
\hline cis-6,-9,-12,-15 $18: 4$ & - & - & - & 3.2 \\
\hline cis- $11,-1420: 2$ & - & - & 0.3 & 0.3 \\
\hline $22: 0$ & - & - & - & 0.2 \\
\hline cis-11,-14,-17 20:3 & - & - & - & 0.2 \\
\hline cis-5,-8,-11,-14 20:4 & - & - & - & 1.0 \\
\hline cis- $13,-1622: 2$ & - & - & - & 1.6 \\
\hline cis- $-5,-8,-11,-14,-1720: 5$ & - & - & - & 13.6 \\
\hline $24: 0$ & - & - & - & 0.1 \\
\hline cis-13,-16,-19 22:3 & - & - & - & 0.3 \\
\hline cis-9 24:1 & - & - & - & 0.3 \\
\hline cis- $7,-10,-13,-1622: 4$ & - & - & - & 0.2 \\
\hline cis- $4,-7,-10,-13,-1622: 5$ & - & - & - & 0.6 \\
\hline cis-7,-10,-13,-16,-19 22:5 & - & - & - & 2.8 \\
\hline cis- $4,-7,-10,-13,-16,-1922: 6$ & - & - & - & 14.6 \\
\hline $18: 1$ cyclo $^{5}$ & - & - & 5.4 & - \\
\hline $19: 1$ cyclo $^{5}$ & - & - & 43.6 & - \\
\hline cis-9,trans-11 18:2 & - & 38.7 & - & - \\
\hline trans -10, cis $-12 \quad 18: 2$ & - & 38.6 & - & - \\
\hline Others $^{6}$ & 1.9 & 2.8 & 9.7 & 3.0 \\
\hline
\end{tabular}

${ }^{1}$ Energy Booster 100 (Milk Specialties Global, Eden Prairie, MN).

${ }^{2}$ Tonalin (Cognis Canada Corp., Mississauga, ON, Canada).

${ }^{3}$ Virginia Prime Gold Menhaden Oil (Omega Protein Inc., Houston, TX).

4

${ }^{5}$ Cyclo $=$ presence of cyclopropene ring $[18: 1$ cyclo $=7$-(2-octyl-1-cyclopropenyl)heptanoic acid (malvalic acid) and 19:1 cyclo is 8-(2-octyl-1-cyclopropenyl) octanoic acid (sterculic acid)].

${ }^{6}$ Represent unidentified chromatogram peaks.

(2013). Glycerol in milk fat was calculated as described by Schauff et al. (1992).

A mammary biopsy $(\sim 25 \mathrm{mg})$ was harvested 3 to $4 \mathrm{~h}$ after the a.m. milking, as described by Gervais et al. (2009), on d 14 of each infusion period. For RNA extraction, tissue was homogenized in TRI Reagent (Molecular Research Center Inc., Cincinnati, OH) using a glass homogenizer, followed by isolation of total RNA according to the instructions of the manufacturer. The RNA pellets were resuspended in RNase-free water and quantified at $260 \mathrm{~nm}$ using a ND-1000 spectrophotometer (NanoDrop Products, Wilmington, DE). Total RNA was reverse transcribed (500 ng per reaction) into cDNA using the Omniscript reverse-transcription kit
(Qiagen Inc., Valencia, CA) according to the instructions of the manufacturer, with oligo(dT) (Eurofins MWG Operon, Huntsville, AL) as the primer.

Real-time PCR reactions were performed using the QuantiTect SYBR Green PCR kit (Qiagen Inc.) and an Applied Biosystems 7300 Real-Time PCR machine (Applied Biosystems Inc., Foster City, CA). Quantification of gene transcripts for $S C D-1$ and $S C D-5$ was completed using gene-specific primers (Table 4). $\beta$-Actin was used as the endogenous control. Fold change was calculated using the $2^{-\Delta \Delta C T}$ method (Livak and Schmittgen, 2001), where $C \mathrm{~T}=$ cycle threshold, with the control group serving as the comparator. The $2^{-\Delta \Delta C T}$ values were used to determine statistical treat- 
Table 3. Amount of lipid emulsion ingredients and FA abomasally infused on a daily basis

\begin{tabular}{|c|c|c|c|c|}
\hline \multirow[b]{2}{*}{ Item } & \multicolumn{4}{|c|}{ Treatment $^{1}$} \\
\hline & CTL & CLA & STO & FO \\
\hline \multicolumn{5}{|l|}{ Ingredient $(\mathrm{g} / \mathrm{d})$} \\
\hline Tap water & 4,509 & 4,509 & 4.509 & 4.509 \\
\hline Whey protein concentrate ${ }^{2}$ & 66 & 66 & 66 & 66 \\
\hline Tween $80^{3}$ & 19 & 19 & 19 & 19 \\
\hline \multicolumn{5}{|l|}{ Experimental fats } \\
\hline $\mathrm{SFA}^{4}$ & 406 & 370 & 399 & 0 \\
\hline $\mathrm{CLA}^{5}$ & 0 & 36 & 0 & 0 \\
\hline Sterculia foetida oil & 0 & 0 & 7 & 0 \\
\hline Fish oil ${ }^{6}$ & 0 & 0 & 0 & 406 \\
\hline Total & 5,000 & 5,000 & 5,000 & 5,000 \\
\hline \multicolumn{5}{|l|}{$\mathrm{FA}$} \\
\hline 14:0 & 17.5 & 15.9 & 17.2 & 36.1 \\
\hline cis-9 14:1 & $-^{7}$ & - & - & 0.4 \\
\hline $15: 0$ & 2.0 & 1.9 & 2.0 & 3.7 \\
\hline $16: 0$ & 112.1 & 102.5 & 111.5 & 77.1 \\
\hline trans-9 16:1 & 1.2 & 1.1 & 1.2 & - \\
\hline cis-9 16:1 & 3.2 & 3.0 & 3.2 & 46.3 \\
\hline $17: 0$ & 6.5 & 5.9 & 6.4 & 2.4 \\
\hline $18: 0$ & 229.8 & 210.4 & 226.1 & 13.4 \\
\hline cis-9 18:1 & 20.3 & 23.9 & 20.5 & 23.1 \\
\hline cis-11 18:1 & 0.8 & 1.0 & 0.9 & 12.2 \\
\hline cis-9,-12 18:2 & 2.0 & 1.9 & 2.5 & 6.1 \\
\hline $20: 0$ & 3.2 & 3.0 & 3.2 & 0.8 \\
\hline cis-6,-9,-12 18:3 & - & - & - & 1.2 \\
\hline cis-9 20:1 & - & - & - & 2.0 \\
\hline cis-11 20:1 & - & - & - & 3.7 \\
\hline cis-9,-12,-15 18:3 & - & - & - & 6.9 \\
\hline cis-6,-9,-12,-15 18:4 & - & - & - & 13.0 \\
\hline cis-11,-14 20:2 & - & - & - & 1.2 \\
\hline $22: 0$ & - & - & - & 0.8 \\
\hline cis-11,-14,-17 20:3 & - & - & - & 0.8 \\
\hline cis- $5,-8,-11,-1420: 4$ & - & - & - & 4.1 \\
\hline cis-13,-16 22:2 & - & - & - & 6.5 \\
\hline cis- $5,-8,-11,-14,-1720: 5$ & - & - & - & 55.2 \\
\hline $24: 0$ & - & - & - & 0.4 \\
\hline cis-13,-16,-19 22:3 & - & - & - & 1.2 \\
\hline cis-9 24:1 & - & - & - & 1.2 \\
\hline cis-7,-10,-13,-16 22:4 & - & - & - & 0.8 \\
\hline cis $-4,-7,-10,-13,-1622: 5$ & - & - & - & 2.4 \\
\hline cis-7,-10,-13,-16,-19 22:5 & - & - & - & 11.4 \\
\hline cis- $4,-7,-10,-13,-16,-1922: 6$ & - & - & - & 59.3 \\
\hline $18: 1$ cyclo $^{8}$ & - & - & 0.4 & - \\
\hline 19:1 cyclo $^{8}$ & - & - & 3.1 & - \\
\hline cis-9,trans-11 18:2 & - & 13.9 & - & - \\
\hline trans -10, cis-12 18:2 & - & 13.9 & - & - \\
\hline Others $^{9}$ & 7.7 & 8.0 & 8.3 & 12.2 \\
\hline \multicolumn{5}{|c|}{$\overline{{ }^{1} \mathrm{CTL}}=$ control $; \mathrm{STO}=$ Sterculia foetida oil; $\mathrm{FO}=$ fish oil. } \\
\hline \multicolumn{5}{|c|}{${ }^{2}$ AMP 80 (American Meat Protein Corp., Boone, IA). } \\
\hline \multicolumn{5}{|c|}{${ }^{3}$ Fisher Scientific (Fair Lawn, NJ). } \\
\hline \multicolumn{5}{|c|}{${ }^{4}$ Energy Booster 100 (Milk Specialties Global, Eden Prairie, MN). } \\
\hline \multicolumn{5}{|c|}{${ }^{5}$ Tonalin (Cognis Canada Corp., Mississauga, ON, Canada). } \\
\hline \multirow{2}{*}{\multicolumn{5}{|c|}{$\begin{array}{l}{ }^{6} \text { Virginia Prime Gold Menhaden Oil (Omega Protein Inc., Houston, TX). } \\
7 \text { - = not detected. }\end{array}$}} \\
\hline & & & & \\
\hline $\begin{array}{l}{ }^{8} \text { Cyclo }=\text { presence of cyclopr } \\
\text { and } 19: 1 \text { cyclo is } 8 \text { - }(2 \text {-octyl- }\end{array}$ & $\begin{array}{l}\text { is } 7-(2- \\
\text { oic acid }\end{array}$ & $\begin{array}{l}\text { cloprop } \\
\text { acid)]. }\end{array}$ & ptanoic & alvalic acid) \\
\hline
\end{tabular}

ment differences. Reaction conditions were as follows: one cycle at $95^{\circ} \mathrm{C}$ for $10 \mathrm{~min}$, followed by 40 cycles at $95^{\circ} \mathrm{C}$ for $30 \mathrm{~s}, 58^{\circ} \mathrm{C}$ for $30 \mathrm{~s}$, and $72^{\circ} \mathrm{C}$ for $1 \mathrm{~min}$. Each reaction was performed in duplicate wells.

\section{Statistical Analysis}

Body weight, DMI, and milk performance values were averaged by period before data analysis. Data were 
Table 4. Summary of genes, primers, and product sizes

\begin{tabular}{|c|c|c|}
\hline Gene $^{1}$ & Primer sequence ${ }^{2} 5^{\prime}-3^{\prime}$ & $\begin{array}{l}\text { Product size } \\
\text { (bp) }\end{array}$ \\
\hline$S C D-1$ & $\begin{array}{l}\text { F: CCCTTTCCTTGAGCTGTCTG } \\
\text { R: ATGCTGACTCTCTCCCCTGA }\end{array}$ & 180 \\
\hline$S C D-5$ & $\begin{array}{l}\text { F: AGAAGGGGAGGAAGCTTGAC } \\
\text { R: GGAGGCCAGGAAGTAGGAGT }\end{array}$ & 166 \\
\hline$\beta$-Actin & $\begin{array}{l}\text { F: CTCTTCCAGCCTTCCTTCCT } \\
\text { R: GGGCAGTGATCTCTTTCTGC }\end{array}$ & 178 \\
\hline
\end{tabular}

${ }^{1} S C D-1=$ stearoyl-CoA desaturase- $1 ; S C D-5=$ stearoyl-CoA desaturase- 5 .

${ }^{2} \mathrm{~F}=$ forward; $\mathrm{R}=$ reverse.

analyzed with PROC MIXED of SAS (SAS Institute Inc., Cary, NC). Because no square effect was observed, it was removed from the model, and data were analyzed as a $4 \times 8$ Latin rectangle design according to the following model:

$$
\mathrm{Y}_{\mathrm{ijk} \mathrm{k}}=\mu+\mathrm{T}_{\mathrm{i}}+\mathrm{P}_{\mathrm{j}}+\mathrm{C}_{\mathrm{k}}+\varepsilon_{\mathrm{ijkl}},
$$

where $Y_{\mathrm{ijkl}}=$ individual observation, $\mu=$ overall mean, $\mathrm{T}_{\mathrm{i}}=$ fixed effect of treatment $(\mathrm{i}=1$ to 4$), \mathrm{P}_{\mathrm{j}}=$ fixed effect of period ( $\mathrm{j}=1$ to 4$), \mathrm{C}_{\mathrm{k}}=$ random effect of cow $(\mathrm{k}=1$ to 8$), \varepsilon_{\mathrm{ijkl}}=$ residual error term, and where the subject of the repeated statement was cow. The covariance structure selection was based on the Akaike information criterion. Preplanned contrasts were used to evaluate the individual effect of experimental FA supplements (CLA, STO, and FO) versus SFA (CTL). Differences between treatments were declared at $P \leq$ 0.05 and tendencies from $P>0.05$ to $P<0.10$.

\section{RESULTS AND DISCUSSION}

Abomasal infusions of SFA (CTL), CLA, STO, and FO were provided to dairy cows in an effort to understand how they affect production performance and the $\Delta^{9}$-desaturation process in lactating ruminants. Dairy cows were abomasally infused as a convenient method to avoid ruminal biohydrogenation of experimental FA. As main or potentially active FA, abomasal infusion of CLA provided $13.9 \mathrm{~g}$ of trans-10,cis-12 18:2, STO provided $3.1 \mathrm{~g}$ of 19:1 cyclo, and FO provided $55.2 \mathrm{~g}$ of cis-5,-8,-11,-14,-17 20:5 + 59.3 g of cis-4,-7,-10,-13,-16,19 22:6, on a daily basis (Table 3). Saturated FA were used in CLA and STO treatments $(>200 \mathrm{~g} / \mathrm{d}$ of 18:0 and $>100 \mathrm{~g} / \mathrm{d}$ of 16:0) to obtain isolipidic supplies and to provide additional substrates for $\Delta^{9}$-desaturation.

\section{Animal Performance}

Compared with CTL, abomasal infusion of CLA, STO, and FO supplements over a 14-d period did not significantly alter BW $(P \geq 0.11)$, which averaged $648 \pm 13 \mathrm{~kg}$ (Table 5). Differences in BW were not expected, considering the isolipidic supplementations $(406 \mathrm{~g} / \mathrm{d})$ and the short period of infusion treatments.

Infusion of CLA and STO did not affect DMI, but FO tended to decrease the amount of feed consumed, compared with CTL $(P=0.09$; Table 5$)$. In a previous study by Drackley et al. (1992) using a similar approach with isolipidic abomasal infusions of FA emulsion, a linear decrease in DMI was observed with increasing unsaturation and chain length of FA supplements. The reduction of feed intake was attributed by those authors to a negative effect of unsaturated FA on postruminal digestion processes.

Abomasal infusion of CLA and FO did not affect milk yield compared with CTL (Table 5). However, infusion of STO decreased milk yield by $13 \%$. Previous experiments have shown no effect (Griinari et al., 2000; Corl et al., 2001) or a decrease (-5.1\%; Kay et al., 2004) in milk yield when STO was abomasally infused for $4 \mathrm{~d}$. The level of STO infusion used in the current trial (7.0 $\mathrm{g} / \mathrm{d}$ ) was slightly lower than daily amounts supplied in previously quoted experiments $(8.8$ to $9.7 \mathrm{~g} / \mathrm{d}$ ), and was provided for a longer period of time $(14 \mathrm{~d})$, along with a source of SFA. Longer treatment periods may explain a

Table 5. Body weight, DMI, milk yield, and concentration and yield of milk fat in lactating dairy cows during abomasal infusion of lipid emulsions

\begin{tabular}{|c|c|c|c|c|c|c|c|c|}
\hline \multirow[b]{2}{*}{ Variable } & \multicolumn{4}{|c|}{ Treatment $^{1}$} & \multirow[b]{2}{*}{ SEM } & \multicolumn{3}{|c|}{$P$-value, CTL vs. } \\
\hline & CTL & CLA & STO & $\mathrm{FO}$ & & CLA & STO & FO \\
\hline BW (kg) & 648 & 656 & 646 & 645 & 13 & 0.11 & 0.56 & 0.51 \\
\hline DMI $(\mathrm{kg} / \mathrm{d})$ & 24.5 & 24.0 & 25.2 & 22.8 & 0.9 & 0.64 & 0.47 & 0.09 \\
\hline Milk yield $(\mathrm{kg} / \mathrm{d})$ & 38.0 & 35.7 & 33.0 & 35.6 & 2.4 & 0.21 & $<0.01$ & 0.19 \\
\hline Milk fat & & & & & & & & \\
\hline$\%$ & 3.79 & 2.23 & 4.45 & 3.34 & 0.12 & $<0.01$ & $<0.01$ & $<0.01$ \\
\hline $\mathrm{g} / \mathrm{d}$ & 1,431 & 774 & 1,475 & 1,186 & 65 & $<0.01$ & 0.32 & $<0.01$ \\
\hline
\end{tabular}

${ }^{1}$ Daily abomasal infusion of control $(\mathrm{CTL})=406 \mathrm{~g}$ of SFA, CLA $=370 \mathrm{~g}$ of SFA $+36 \mathrm{~g}$ of CLA, STO $=399$ $\mathrm{g}$ of SFA $+7 \mathrm{~g}$ of Sterculia foetida oil, and FO $=406 \mathrm{~g}$ of fish oil. 
more pronounced effect on milk yield. In addition, the combination of 19:1 cyclo with an SFA diet has been shown to cause harmful effects in rodents, such as a lower conception rate and a decreased growth rate of pups (Nixon et al., 1977). However, animals were able to tolerate the same levels of 19:1 cyclo when a source of unsaturated dietary lipid was provided in their diet (Nixon et al., 1977). It is possible to hypothesize that, under the conditions of the current experiment, detrimental effects of STO would have been limited to a decrease in milk yield, considering that unsaturated FA were available from the diet in all treatments.

Infusion of CLA decreased milk fat concentration and yield by 41 and $46 \%$, respectively (Table 5 ). These results are consistent with those from several studies in which CLA mixtures containing trans-10, cis-12 18:2 decreased milk fat when supplemented as abomasal infusion (Chouinard et al., 1999a,b; Baumgard et al., 2002), calcium salts (Gervais et al., 2005), or intravenous infusion (Gervais et al., 2009). Baumgard et al. (2002) have shown that trans-10,cis-12 18:2 decreases the expression of genes involved in milk lipid synthesis in dairy cows. The decline of $46 \%$ in the milk fat yield observed in the present study following abomasal infusion of $13.9 \mathrm{~g} / \mathrm{d}$ of trans-10,cis-12 18:2 is in the range of what would be predicted, based on the correlation established previously using combined results from several experiments involving abomasal infusion of CLA (de Veth et al., 2004).

Abomasal infusion of FO also decreased milk fat concentration and yield by 12 and $17 \%$, respectively (Table 5). Similar responses in milk fat concentration were reported following an abomasal infusion of cod liver oil (225 g/d; Pennington and Davis, 1975), or a duodenal infusion of menhaden oil (276 g/d; Loor et al., 2005), although milk fat yield was not affected in either trial. The presence of cis-5,-8,-11,-14,-17 20:5 and cis-4,-7,$10,-13,-16,-1922: 6$ may account for the reduction in milk fat concentration in response to postruminal FO supply. In this regard, Ahnadi et al. (2002) have shown that feeding protected FO, increasing postruminal supply of cis-5,-8,-11,-14,-17 20:5 and cis-4,-7,-10,-13,-16,19 22:6, inhibited expression of genes implicated in milk fat synthesis in dairy cows. In contrast, Hussein et al. (2013b) reported no effect of FO on lipogenic capacity of mammary explants from lactating mice.

Milk fat concentration was increased by $17 \%$ when STO was infused compared with CTL (Table 5). However, as a consequence of lower milk production, daily fat yield was not different between these 2 treatments. Consistent with these results, Corl et al. (2001) observed an increase in milk fat concentration, with no effect on milk fat yield, when STO was abomasally infused.

\section{Milk FA Yield and Profile}

Abomasal supply of trans-10,cis-12 $18: 2(13.9 \mathrm{~g} / \mathrm{d}$; Table 3 ) was taken up by mammary gland and secreted into milk $(2.8 \mathrm{~g} / \mathrm{d}$; Table 6$)$ with an efficiency of $19.9 \%$, which is comparable with results from previous experiments (Chouinard et al., 1999b; de Veth et al., 2004). When evaluating the secretion of 19:1 cyclo from abomasally infused STO, it must be taken into account that this FA coelutes with trans-8,cis-13 18:2 in milk fat chromatograms (Table 6). Assuming a similar rate of secretion of this minor 18:2 isomer for CTL (0.49 $\mathrm{g} / \mathrm{d}$; Table 6) and STO, one can calculate a secretion of 19:1 cyclo of $1.07 \mathrm{~g} / \mathrm{d}$ and an efficiency of transfer from abomasal infusion to milk fat of $35.0 \%$. The recoveries (i.e., response above CTL group) of abomasally infused cis-5,-8,-11,-14,-17 20:5, cis-7,-10,-13,-16,-19 $22: 5$, and cis-4,-7,-10,-13,-16,-19 22:6 from FO were $36.6,55.5$, and $25.9 \%$, respectively. Hagemeister et al. (1988) reported a transfer efficiency ranging from 35 to $40 \%$ for n-3 FA of menhaden oil infused into the abomasum at the rate of 220 to $420 \mathrm{~g} / \mathrm{d}$, whereas Loor et al. (2005) calculated a recovery of $14.4,51.1$, and $13.3 \%$ for cis- $5,-8,-11,-14,-1720: 5$, cis-7,-10,-13,-16,-19 $22: 5$ and cis- $4,-7,-10,-13,-16,-1922: 6$, respectively, when infusing menhaden oil into the duodenum at the rate of $276 \mathrm{~g} / \mathrm{d}$. The greater recovery rate observed for $\mathrm{cis}$ $7,-10,-13,-16,-1922: 5$ suggests that (1) this FA is used more efficiently by the mammary gland or (2) cis-5,8,-11,-14,-17 20:5 and cis-4,-7,-10,-13,-16,-19 22:6 are spared for other purposes in the animal body (Chilliard et al., 2000). It can also be hypothesized that cis-7,$10,-13,-16,-1922: 5$ was produced by the elongation of cis-5,-8,-11,-14,-17 20:5. Taken together, all calculated recovery rates obtained in the current trial show that preparation of emulsions and continuous abomasal infusions were efficient to deliver the potentially active FA to dairy cows.

In dairy cattle, milk FA originate either from de novo synthesis or from the uptake of preformed lipids (Palmquist and Jenkins, 1980). Even short- and medium-chain FA (C4 to C14), plus a portion of $\mathrm{C} 16$ FA are synthesized de novo by the mammary epithelial cells. In contrast, odd- and branched-chain FA as well as those with chains of 18 carbons and longer, plus a portion of C16 FA are taken up by the mammary gland from the blood and incorporated into milk fat.

Infusion of CLA decreased the yields of most milk FA and glycerol (Table 6 ). The mechanism by which CLA affects milk fat synthesis involves (1) an inhibition of de novo FA synthesis in the mammary gland, with a lower abundance of mRNA of acetyl-CoA carboxylase and FA synthetase and (2) a decrease in mammary uptake of preformed FA and their incorporation into 
Table 6. Yields of milk FA and glycerol in lactating dairy cows during abomasal infusion of lipid emulsions

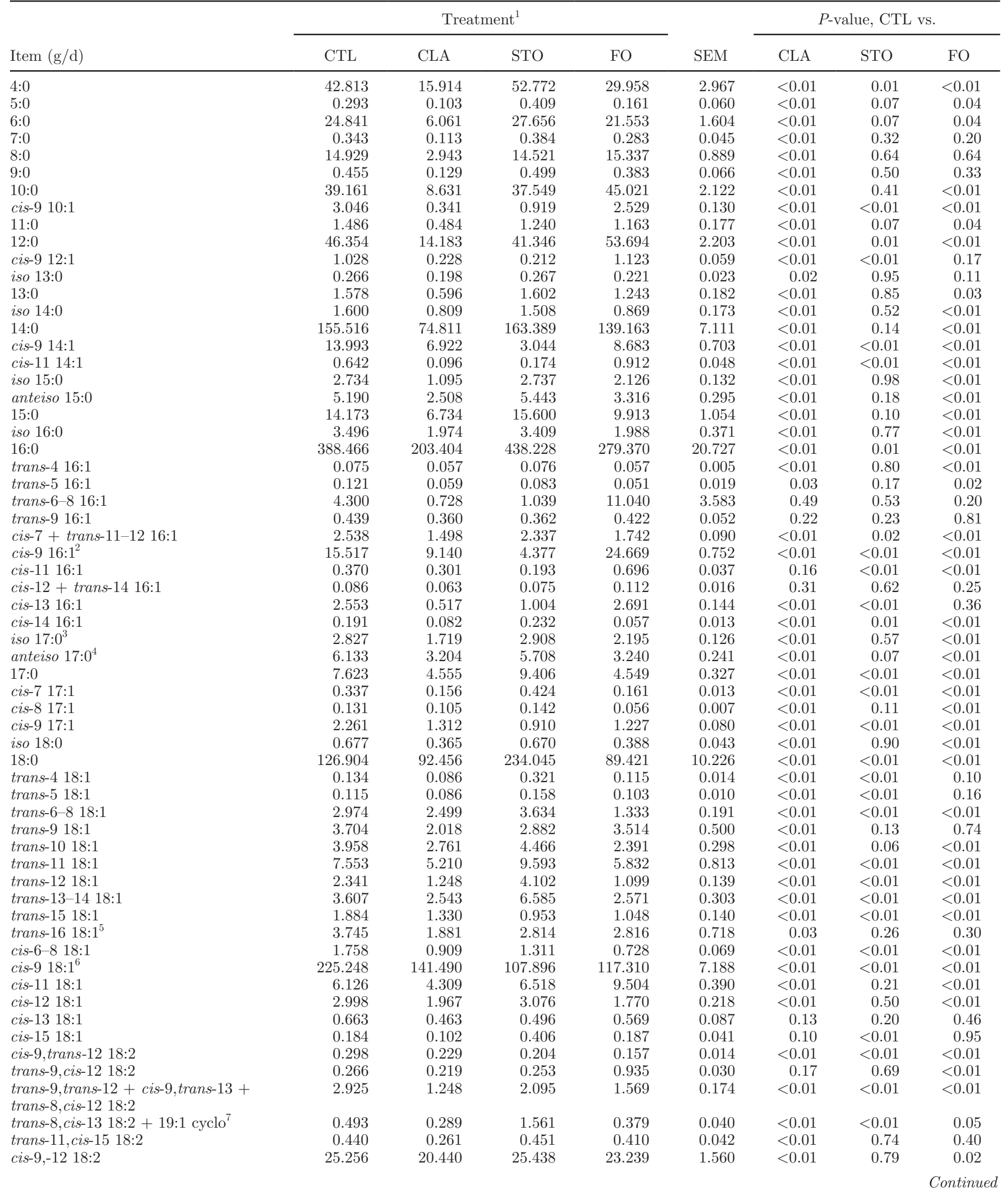


Table 6 (Continued). Yields of milk FA and glycerol in lactating dairy cows during abomasal infusion of lipid emulsions

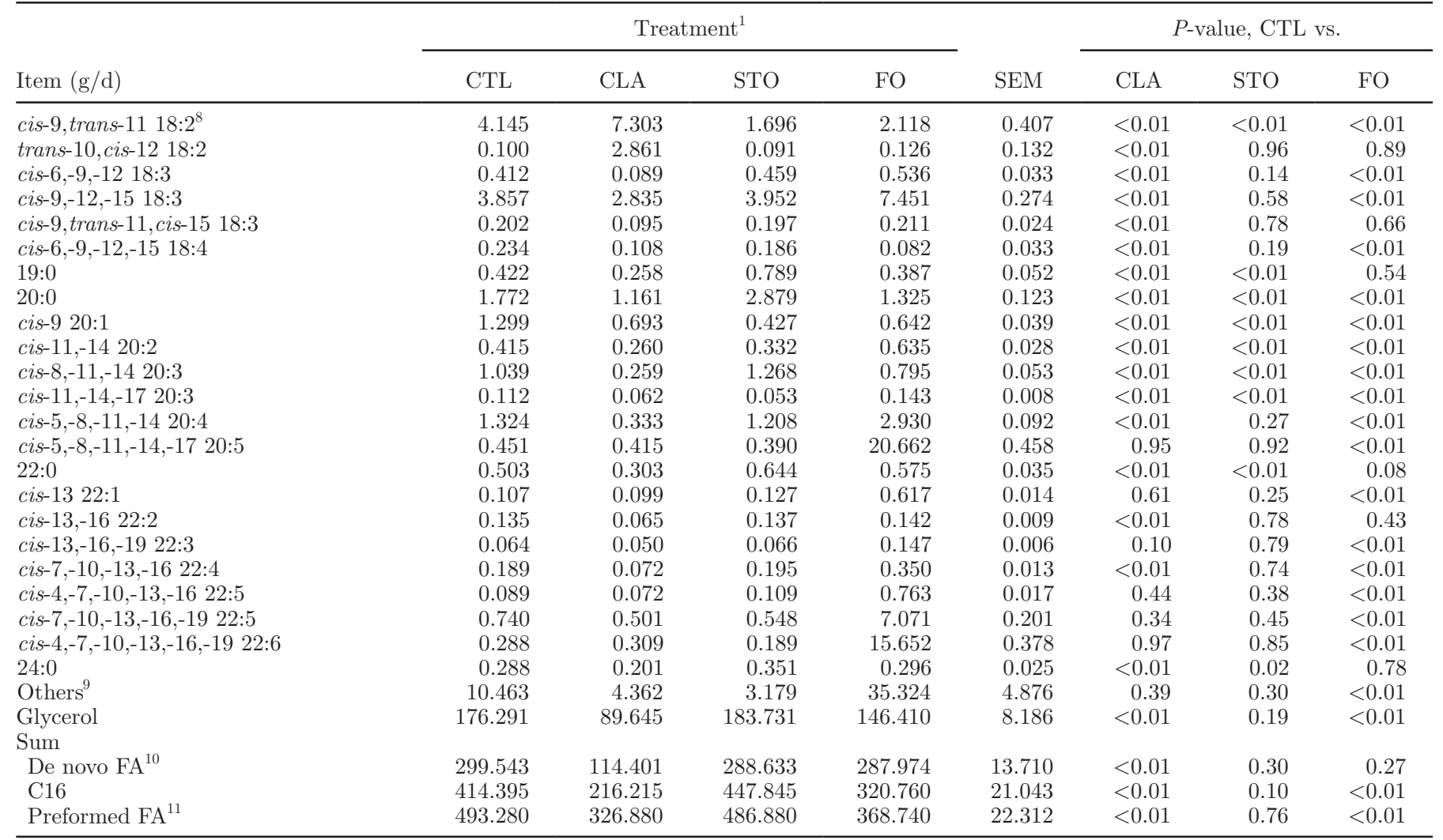

${ }^{1}$ Daily abomasal infusion of control $(\mathrm{CTL})=406 \mathrm{~g}$ of SFA, CLA $=370 \mathrm{~g}$ of SFA $+36 \mathrm{~g}$ of CLA, STO $=399 \mathrm{~g}$ of SFA $+7 \mathrm{~g}$ of Sterculia foetida oil, and $\mathrm{FO}=406 \mathrm{~g}$ of fish oil.

${ }^{2}$ Coelution with minor concentration of trans-13 16:1.

${ }^{3}$ Coelution with minor concentration of trans-10 16:1.

${ }^{4}$ Coelution with minor concentration of cis-10 16:1.

${ }^{5}$ Coelution with minor concentration of cis-14 18:1

${ }^{6}$ Coelution with minor concentration of cis-10 18:1.

${ }^{7}$ Cyclo $=$ presence of cyclopropene ring [19:1 cyclo is 8-(2-octyl-1-cyclopropenyl)octanoic acid (sterculic acid)].

${ }^{8}$ Coelution with minor concentration of trans-7,cis-9 18:2.

${ }^{9}$ Represent unidentified chromatogram peaks.

${ }^{10}$ Sum of straight even-chain FA from C6 to C14.

${ }^{11}$ Sum of branched-chain FA (iso 13:0, iso 14:0, iso 15:0, anteiso 15:0, iso 16:0, iso 17:0, and anteiso 17:0), odd-chain FA (13:0 and 15:0), and all FA with a chain length of $17 \mathrm{C}$ or more.

milk fat, with lower mRNA abundance of lipoprotein lipase and FA-binding protein (Baumgard et al., 2002; Gervais et al., 2009). In the current experiment, CLA infusion decreased the yield of de novo synthesized FA to a greater extent $(-62 \%)$, compared with preformed FA ( $-34 \%$; Table 6$)$. As the magnitude of decrease differed among FA, the CLA supplementation altered the FA profile of milk fat (Table 7). Among major FA, the proportions of 4:0, 6:0, 8:0, 10:0, 12:0, 14:0, cis-9 14:1, 15:0 decreased; the proportions of 17:0, 18:0, trans -11 18:1, cis-9 18:1, cis-11 18:1, cis-9,-12 18:2, cis-9,-12,-15 18:3 increased; and the proportions of $16: 0$ and cis-9 16:1 were not affected. Lower milk fat concentration of short- and medium-chain FA (4 to 14 carbons), and a greater proportion of 18-carbon FA in milk fat with CLA treatment may explain the decrease in milk fat concentration of glycerol observed in the current study (Table 7). On a weight basis, less glycerol is actually required to esterify long-chain than short-chain FA during milk triglyceride synthesis.

Infusion of STO increased the secretion of total C16 FA (Table 6), and the proportion of 16:0 (Table 7) in milk fat. However, STO did not significantly affect the yield of de novo synthesized or preformed FA compared with CTL (Table 6). Despite significant variations in the proportions of some individual FA (discussed in the following section), no shift between de novo synthesized or preformed FA was apparent. These results are in 
Table 7. Milk fat composition in lactating dairy cows during abomasal infusion of lipid emulsions

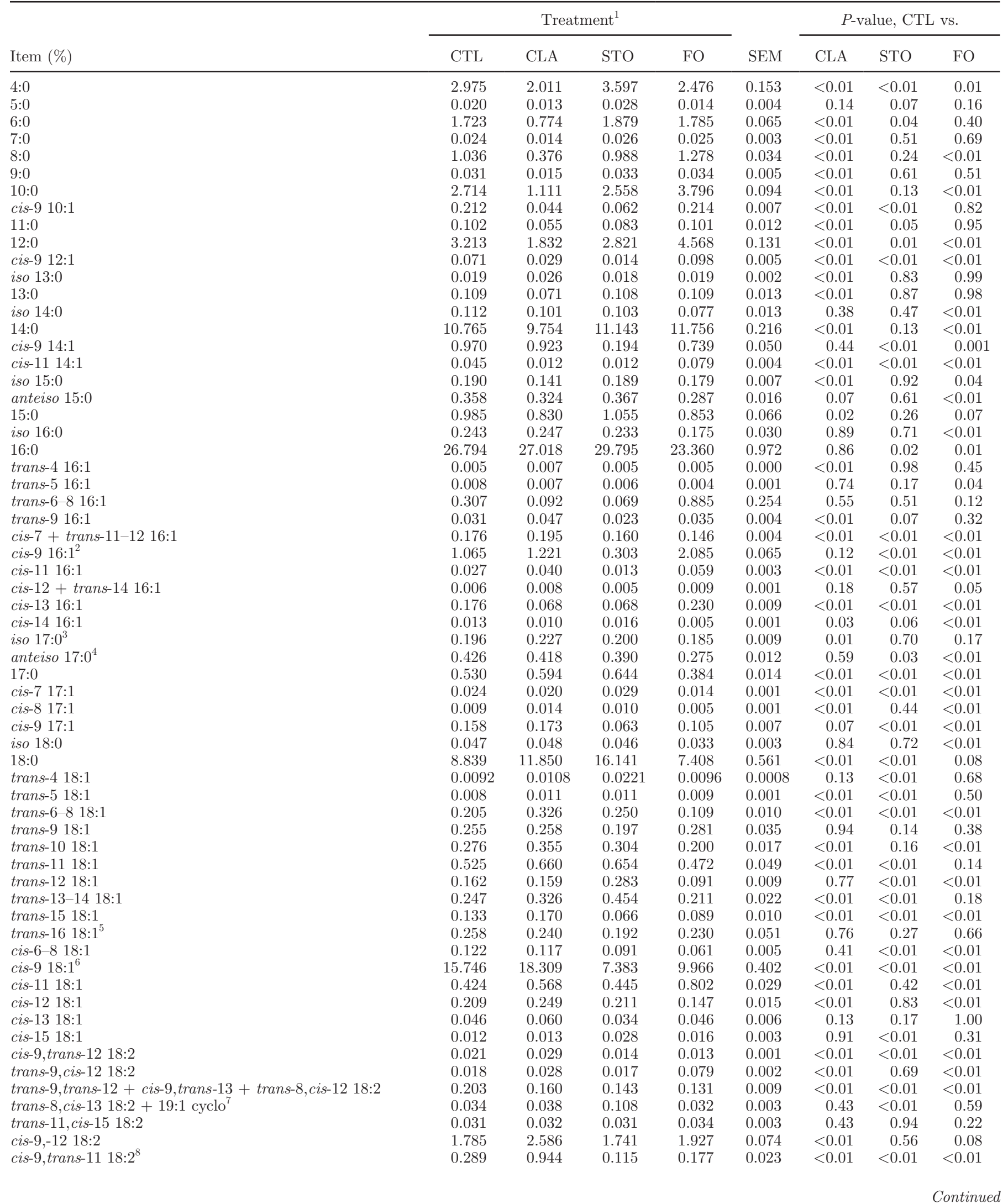


Table 7 (Continued). Milk fat composition in lactating dairy cows during abomasal infusion of lipid emulsions

\begin{tabular}{|c|c|c|c|c|c|c|c|c|}
\hline Item $(\%)$ & \multicolumn{4}{|c|}{ Treatment $^{1}$} & SEM & \multicolumn{3}{|c|}{$P$-value, CTL vs. } \\
\hline trans-10,cis-12 18:2 & 0.007 & 0.374 & 0.006 & 0.011 & 0.013 & $<0.01$ & 0.99 & 0.82 \\
\hline cis-9,-12,-15 18:3 & 0.273 & 0.373 & 0.263 & 0.624 & 0.013 & $<0.01$ & 0.51 & $<0.01$ \\
\hline cis-9,trans-11,cis-15 18:3 & 0.013 & 0.013 & 0.013 & 0.019 & 0.002 & 0.68 & 0.67 & 0.02 \\
\hline cis-6,-9,-12,-15 18:4 & 0.016 & 0.014 & 0.013 & 0.007 & 0.002 & 0.57 & 0.24 & $<0.01$ \\
\hline cis-9 20:1 & 0.091 & 0.090 & 0.029 & 0.055 & 0.003 & 0.65 & $<0.01$ & $<0.01$ \\
\hline cis-11,-14 20:2 & 0.029 & 0.033 & 0.023 & 0.054 & 0.002 & 0.10 & 0.01 & $<0.01$ \\
\hline cis-8,-11,-14 20:3 & 0.072 & 0.033 & 0.089 & 0.068 & 0.006 & $<0.01$ & 0.01 & 0.50 \\
\hline cis-11,-14,-17 20:3 & 0.008 & 0.008 & 0.003 & 0.012 & 0.001 & 0.79 & $<0.01$ & $<0.01$ \\
\hline cis $-5,-8,-11,-1420: 4$ & 0.089 & 0.047 & 0.077 & 0.253 & 0.007 & $<0.01$ & 0.06 & $<0.01$ \\
\hline cis $-5,-8,-11,-14,-1720: 5$ & 0.032 & 0.056 & 0.026 & 1.754 & 0.026 & 0.51 & 0.87 & $<0.01$ \\
\hline $22: 0$ & 0.035 & 0.040 & 0.044 & 0.049 & 0.002 & 0.06 & $<0.01$ & $<0.01$ \\
\hline cis- $7,-10,-13,-16,-1922: 5$ & 0.054 & 0.069 & 0.032 & 0.605 & 0.016 & 0.41 & 0.26 & $<0.01$ \\
\hline cis- $4,-7,-10,-13,-16,-1922: 6$ & 0.021 & 0.042 & 0.013 & 1.329 & 0.024 & 0.54 & 0.80 & $<0.01$ \\
\hline $24: 0$ & 0.020 & 0.026 & 0.024 & 0.026 & 0.002 & $<0.01$ & 0.05 & 0.01 \\
\hline Others $^{9}$ & 0.737 & 0.564 & 0.217 & 2.946 & 0.344 & 0.72 & 0.29 & $<0.01$ \\
\hline Glycerol & 12.313 & 11.581 & 12.464 & 12.322 & 0.056 & $<0.01$ & 0.04 & 0.90 \\
\hline \multicolumn{9}{|l|}{ Desaturase index } \\
\hline cis-9 10:1/(10:0 + cis-9 10:1) & 0.073 & 0.039 & 0.023 & 0.054 & 0.003 & $<0.01$ & $<0.01$ & $<0.01$ \\
\hline cis-9 12:1/(12:0 + cis-9 12:1) & 0.022 & 0.016 & 0.004 & 0.021 & 0.001 & $<0.01$ & $<0.01$ & 0.43 \\
\hline cis-9 14:1/(14:0 + cis-9 14:1) & 0.083 & 0.086 & 0.017 & 0.059 & 0.004 & 0.47 & $<0.01$ & $<0.01$ \\
\hline cis-9 16:1/(16:0 + cis-9 16:1) & 0.038 & 0.043 & 0.010 & 0.083 & 0.002 & 0.13 & $<0.01$ & $<0.01$ \\
\hline cis-9 17:1/(17:0 + cis-9 17:1) & 0.228 & 0.226 & 0.088 & 0.214 & 0.007 & 0.79 & $<0.01$ & 0.14 \\
\hline cis-9 18:1/(18:0 + cis-9 18:1) & 0.015 & 0.014 & 0.004 & 0.012 & 0.001 & 0.79 & $<0.01$ & 0.07 \\
\hline cis-9 20:1/(20:0 + cis-9 20:1) & 0.424 & 0.374 & 0.130 & 0.329 & 0.009 & $<0.01$ & $<0.01$ & $<0.01$ \\
\hline cis-9,trans-11 18:2/(trans-11 18:1 + cis-9,trans-11 18:2) & 0.358 & 0.594 & 0.143 & 0.281 & 0.011 & $<0.01$ & $<0.01$ & $<0.01$ \\
\hline
\end{tabular}

${ }^{1}$ Daily abomasal infusion of CTL $=406 \mathrm{~g}$ of SFA, CLA $=370 \mathrm{~g}$ of SFA $+36 \mathrm{~g}$ of CLA, STO $=399 \mathrm{~g}$ of SFA $+7 \mathrm{~g}$ of Sterculia foetida oil; and $\mathrm{FO}=406 \mathrm{~g}$ of fish oil.

${ }^{2}$ Coelution with minor concentration of trans-13 16:1

${ }^{3}$ Coelution with minor concentration of trans-10 16:1.

${ }^{4}$ Coelution with minor concentration of cis-10 16:1.

${ }^{5}$ Coelution with minor concentration of cis-14 18:1.

${ }^{6}$ Coelution with minor concentration of cis-10 18:1.

${ }^{7}$ Cyclo $=$ presence of cyclopropene ring [19:1 cyclo is 8-(2-octyl-1-cyclopropenyl)octanoic acid (sterculic acid)].

${ }^{8}$ Coelution with minor concentration of trans-7,cis-9 18:2.

${ }^{9}$ Represent unidentified chromatogram peaks.

agreement with those reported previously following abomasal STO infusion (Griinari et al., 2000; Corl et al., 2001; Kay et al., 2004), and are consistent with the fact that STO did not modify total fat yield compared with CTL in the current trial (Table 5).

Infusion of FO did not affect the yields of de novo synthesized FA, but decreased the yields of total C16 and preformed FA (Table 6). Among major FA, the yields of 16:0, 18:0, and cis-9 18:1 were reduced by 28,30 , and $48 \%$, respectively (Table 6 ). The increased yields of $\mathrm{C} 20$ and $\mathrm{C} 22 \mathrm{FA}$ from FO did not compensate for lower secretion of 16:0, 18:0, and cis-9 18:1, which were provided in lower amounts in FO compared with CTL. As a result of these changes observed in FA secretion, the proportions of de novo synthesized short- and medium-chain FA (e.g., 8:0, 10:0, 12:0, and 14:0) increased in milk fat (Table 7). Consistently, Loor et al. (2005) also observed increases in percentages of 8:0, 10:0, and 12:0 following duodenal supply of $276 \mathrm{~g}$ of FO/d. Early in vitro work by Brumby et al. (1972) has shown that cod liver oil significantly reduced the rate of triglyceride hydrolysis by mammary lipoprotein lipase. This enzyme is involved in mammary uptake of preformed FA, which may explain the lower yield of this FA class with FO treatment in the current study (Table 6). 


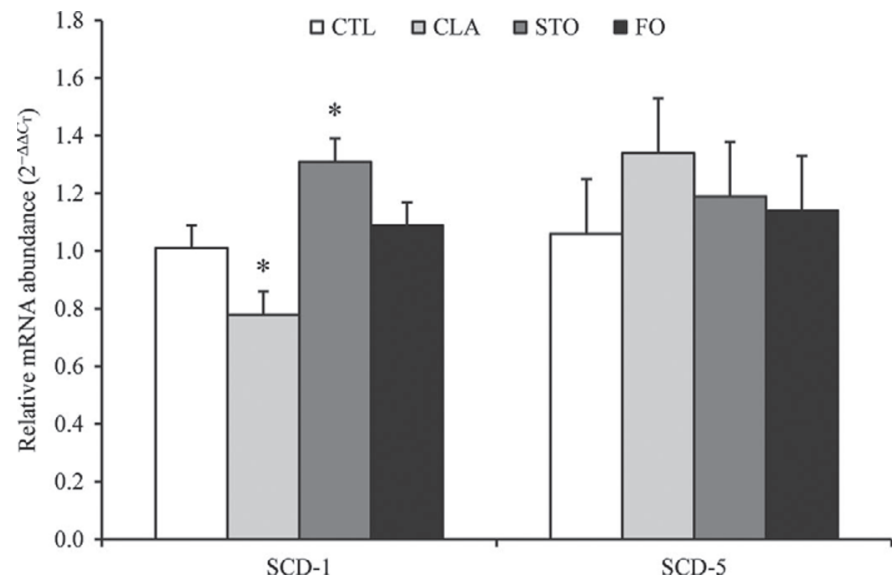

Figure 1. Relative mRNA abundance of genes encoding for stearoyl-CoA desaturase-1 (SCD-1) and stearoyl-CoA desaturase-5 (SCD-5) in mammary tissue of lactating dairy cows after $14 \mathrm{~d}$ of abomasal infusion of lipid emulsions providing $406 \mathrm{~g}$ of SFA (control, CTL), $370 \mathrm{~g}$ of SFA $+36 \mathrm{~g}$ of CLA (CLA), $399 \mathrm{~g}$ of SFA $+7 \mathrm{~g}$ of Sterculia foetida oil (STO), or $406 \mathrm{~g}$ of fish oil (FO) on a daily basis. Data are LSM and their SE. * indicates significant difference compared with CTL treatment $(P<0.05) . C_{\mathrm{T}}=$ cycle threshold.

\section{Apparent FA $\Delta^{9}$-Desaturation Activity}

To assess $\Delta^{9}$-desaturation activity, Kelsey et al. (2003) proposed specific ratios that are calculated by dividing milk fat concentration of a desaturase product by the sum of the desaturase substrate and its product. Stearic acid (18:0) is the primary substrate for the $\Delta^{9}$-desaturase, but this enzyme can also introduce a $\mathrm{cis}$ 9 double bond on many saturated or unsaturated short-, medium-, and long-chain FA (Kay et al., 2004; Bichi et al., 2012). In the current trial, 8 different desaturase indices were calculated (Table 7). Among them, desaturase indices for 10:0, 12:0, and 20:0 were decreased, whereas the extent of desaturation of 14:0, 16:0, 17:0, and 18:0 was not affected by CLA treatment compared with CTL. In contrast, the desaturase index for trans-11
18:1 was increased by CLA infusion. This effect is likely explained by the supply of cis-9,trans-11 18:2 among the conjugated isomers provided in the CLA supplement used during the current trial (Table 2).

In addition to 18:0, 14:0 and 16:0 are considered to be important substrate for $\Delta^{9}$-desaturase. The lack of effect of CLA infusion on the desaturase indices for these FA is not consistent with the lower mammary abundance of mRNA coding for SCD-1 (Table 8; Figure 1). The absence of correlation between $S C D-1$ expression and main desaturase indices has been observed previously by Gervais et al. (2009) using intravenous infusions of CLA. Among the factors that could explain this discrepancy, Bauman et al. (2003) highlighted (1) different gene polymorphisms that could cause variations in primary or tertiary structure of the enzyme, (2) modifications at the posttranslational level, and (3) other mechanisms possibly interfering with the synthesis and secretion of FA related to SCD-1 activity.

Infusion of STO significantly decreased all 8 calculated desaturase indexes compared with CTL (Table 7). Such effects were reported previously with postruminal supply of STO in lactating dairy cows (Griinari et al., 2000; Corl et al., 2001) and ewes (Bichi et al., 2012). In these studies (Griinari et al., 2000; Corl et al., 2001), the ratio of cis-9 14:1 to $14: 0$ was used to estimate the degree of inhibition of $\Delta^{9}$-desaturation. This assessment is based on the premise that 14:0 is predominantly synthesized de novo by the mammary gland and that most of cis-9 14:1 originates from the action of $\Delta^{9}$-desaturase located in mammary epithelial cells, which was further established in vivo by Mosley and McGuire (2007), using abomasal perfusion of ${ }^{13} \mathrm{C}-$ labeled myristic acid $\left(\left[1-{ }^{13} \mathrm{C}\right] 14: 0\right)$. Based on the same assumption, in the current trial, a reduction of $80.7 \%$ of $\Delta^{9}$-desaturation could be calculated (Table 8), which is in agreement with previous estimates ranging from 73 (Griinari et al., 2000) to $83 \%$ (Corl et al., 2001) inhibition when STO was abomasally infused for $4 \mathrm{~d}$.

Table 8. Summary of the effects of lipid emulsions on the extent of $\Delta^{9}$-desaturation and mRNA abundance of stearoyl-CoA desaturase

\begin{tabular}{|c|c|c|c|}
\hline \multirow[b]{2}{*}{ Parameter } & \multicolumn{3}{|c|}{ Treatment $^{1,2}$} \\
\hline & CLA & STO & $\mathrm{FO}$ \\
\hline $\begin{array}{l}\text { Apparent desaturation activity }{ }^{3}(\%) \\
\text { Mammary mRNA abundance of } S C D-1^{5}(\%)\end{array}$ & $\begin{array}{l}\mathrm{NS}^{4} \\
-22.7\end{array}$ & $\begin{array}{l}-80.7 \\
+31.5\end{array}$ & $\begin{array}{l}-30.2 \\
\mathrm{NS}\end{array}$ \\
\hline \multicolumn{4}{|c|}{$\begin{array}{l}{ }^{1} \mathrm{CLA}=370 \mathrm{~g} \text { of SFA }+36 \mathrm{~g} \text { of CLA, STO }=399 \mathrm{~g} \text { of SFA }+7 \mathrm{~g} \text { of Sterculia foetida oil, and FO } \\
\text { fish oil, on a daily basis. } \\
{ }^{2} \text { Treatments were compared with control (abomasal infusion of } 406 \mathrm{~g} \text { of SFA } / \mathrm{d} \text { ) and percentages } \\
\text { for significant differences }(P \leq 0.05) . \\
{ }^{3} \text { Using the ratio cis- } 914: 1 /(14: 0+\text { cis- } 914: 1) \text { to assess the effect on the } \Delta^{9} \text {-desaturation process. } \\
{ }^{4} \mathrm{NS}=\text { not significantly affected }(P>0.10) .\end{array}$} \\
\hline
\end{tabular}


Desaturation of FA at the $\Delta^{9}$ position is an important process in establishing the physical characteristics of milk fat (Shingfield and Griinari, 2007). It has been hypothesized that an inhibition of this reaction could lead to a shortage of monounsaturated FA (e.g., cis-9 18:1) for triglyceride synthesis in the mammary gland, resulting in a decrease in milk fat secretion (Shingfield and Griinari, 2007). In the current trial, infusion of STO did not change the yield of milk fat compared with CTL, despite the acute inhibition of the desaturation process. This lack of effect on total fat secretion suggests that mammary epithelial cells can potentially develop different mechanisms to compensate for the increase in the melting point of triglyceride precursors (Shingfield and Griinari, 2007) to maintain fat globule packaging and secretion.

Despite the fact that STO drastically lowered milk FA desaturase indices, the opposite effect (i.e., a $31.5 \%$ increase) was observed in mammary mRNA abundance of $S C D$-1 (Table 8; Figure 1). Whereas some inhibitors (e.g., sulfur-substituted FA) have been shown to restrain SCD either at the gene expression or at the enzyme activity levels, cyclopropene FA, such as 19:1 cyclo, are known to directly inhibit SCD activity (Miyazaki and Ntambi, 2003). Early work suggested that inhibition of SCD may be explained by an irreversible binding of enzyme sulfhydryl groups by cyclopropene groups (Raju and Reiser, 1967). Further experiments have also shown that the inhibiting effect of 19:1 cyclo on SCD is mediated through the conversion of this cyclopropene FA to its activated form (sterculoyl-CoA; Jeffcoat and Pollard, 1977). The increase in transcription observed in the current trial could be due to the response of mammary cells to a shortage of $\Delta^{9}$-desaturase products (e.g., cis-9 18:1) required to synthesize milk triglycerides. In this regard, Keating et al. (2006) have shown, under in vitro conditions, that cis-9 18:1 downregulates $S C D$ promoter activity, whereas 18:0 did not affect $S C D$ promoter activation. Because the concentration of cis-9 18:1 was decreased by $53 \%$ in milk fat during STO treatment, its negative feedback would have been of a lower magnitude, allowing for greater $S C D-1$ gene transcription.

Abomasal infusion of FO decreased the desaturase indices for 10:0, 14:0, 18:0 (tendency), 20:0, and trans-11 $18: 1$, whereas the extent of desaturation of $12: 0$ and 17:0 was not affected by FO treatment, compared with CTL (Table 7). The ratio of cis-9 16:1 to cis-9 16:1 + 16:0 was significantly greater for the FO treatment, but this effect was attributable to the exogenous cis-9 16:1 from infused menhaden oil $(46.3 \mathrm{~g} / \mathrm{d}$; Table 3$)$. When using the ratio of cis-9 14:1 to cis-9 14:1 + 14:0 to calculate the degree of inhibition, FO infusion is estimated to have reduced $\Delta^{9}$-desaturation by $30.2 \%$ compared with CTL (Table 8). An inhibition of apparent SCD activity $(-24 \%)$ can also be calculated using the FA profile reported by Loor et al. (2005) for cows receiving duodenal infusion of $276 \mathrm{~g}$ of menhaden oil per day.

Polyunsaturated FA, such as cis-5,-8,-11,-14,-17 20:5 and cis-4,-7,-10,-13,-16,-19 22:6, are known to inhibit $S C D-1$ gene expression (Mauvoisin and Mounier 2011). However, the inhibiting effect of FO on apparent desaturase activity observed in the current trial is contradictory with the similar $S C D-1$ mRNA abundances between FO and CTL (Figure 1). On the one hand, Keating et al. (2006) did not find any significant effect of cis-9,-12 18:2 and cis-9,-12,-15 18:3 on in vitro $S C D$ promoter activity in mammary epithelial cells. On the other hand, Ahnadi et al. (2002) observed a strong decrease of more than $60 \%$ of $S C D-1$ mRNA relative abundance after feeding glutaraldehyde-protected FO for 4 wk. However, the efficiency of protection was apparently incomplete in this later trial, as shown by a significant increase in trans 18:1 FA concentration in milk fat. It could, therefore, be hypothesized that $S C D$ inhibition could have been caused by some intermediates of ruminal biohydrogenation, a phenomenon that has been suggested by Bernard et al. (2008).

It is also important to note that, in the current experiment, treatments were designed to be isolipidic. Consequently, CTL treatment had a higher concentration in SFA compared with FO. This variation in substrates could have affected treatment effects on apparent SCD activity.

None of the abomasally infused FA supplements (CLA, STO, and FO) affected the transcript expression of $S C D-5$ compared with CTL (Figure 1). This is in line with results from a previous study that observed, following a CLA treatment, a decrease in $S C D$-1 transcript expression, and no variation in $S C D-5$ transcription (Gervais et al., 2009). This lack of effect is also consistent with the results of Jacobs et al. (2011) who reported no effect of dietary rapeseed, soybean, or linseed oils on mammary mRNA abundance of $S C D-5$ in dairy cows. These observations with varying dietary situations support the concept that regulation of $S C D$ 1 and $S C D-5$ differ significantly, as illustrated by major differences in expression profile (Lengi and Corl, 2007). Moreover, the same authors reported great divergences between the sequence of SCD-1 and SCD-5 proteins (Lengi and Corl, 2007). Mammalian SCD-1 proteins have a relatively short half-life ( 3 to $4 \mathrm{~h}$ ) and are rich in PEST sequences, specific sequences of amino acids believed to be at the origin of the protein instability (Rechsteiner and Rogers, 1996). In contrast, the bovine SCD-5 does not contain PEST sequences, suggesting that this isoform may be more stable and less sensitive to regulation by dietary FA (Lengi and Corl, 2007). 


\section{CONCLUSIONS}

Various FA supplements were evaluated for their effects on lactation performance and $\Delta^{9}$-desaturation activity. The effects of CLA and STO have been evaluated with a concomitant supply of SFA. Moreover, abomasal infusion of FO allowed isolation of its effects, without the interference of ruminal biohydrogenation intermediates, whereas these effects were compared with an isolipidic fat supplementation enriched in SFA (CTL). As expected, the major effect of CLA on animal performance was the inhibition of milk fat yield. Infusion of STO decreased milk yield, whereas the production of fat remained unchanged. As a result, an increased concentration of milk fat was observed. Infusion of FO reduced milk fat concentration and yield, which could be explained by a lower uptake of preformed FA by mammary gland. Abomasal infusions of CLA, STO, and FO have been shown to exhibit varying and distinct effects on desaturase indices, and mammary mRNA abundance of $S C D$-1. Infusion of CLA decreased mammary mRNA abundance of $S C D-1$ without affecting major FA desaturase indices. The opposite phenomenon was observed following FO infusion, with lower desaturase indices and no effect on $S C D-1$ mRNA abundance. As also expected, an acute inhibition of apparent desaturase activity was observed following postruminal supply of STO. However, this inhibition was accompanied by a higher relative mRNA abundance of genes encoding for SCD-1, which was tentatively explained by the reduced magnitude of the negative feedback exerted on $S C D$ 1 gene transcription by its main product (cis-9 18:1). Such incomplete association between desaturation indices and mRNA abundance of $S C D-1$ demonstrates the difficulty of using these proxies in relation to gene expression of $S C D$. Finally, no effect was observed on mRNA abundance of $S C D$-5, which confirms that this isoform is less sensitive than SCD-1 to regulation by dietary FA.

\section{ACKNOWLEDGMENTS}

This work was supported by a grant from the Natural Sciences and Engineering Research Council of Canada (Ottawa, ON, Canada). The authors gratefully acknowledge the donation of CLA supplement by Cognis Canada Corp. (Mississauga, ON, Canada) and menhaden oil by Omega Protein Inc. (Houston, TX). Sincere appreciation is also extended to the administration and staff of the Centre de Recherche en Sciences Animales de Deschambault (Portneuf, QC, Canada) for care and feeding of cows. The assistance of Micheline Gingras of Université Laval (Québec, QC, Canada) is also gratefully appreciated.

\section{REFERENCES}

Ahnadi, C. E., N. Beswick, L. Delbecchi, J. J. Kennelly, and P. Lacasse. 2002. Addition of fish oil to diets for dairy cows. II. Effects on milk fat and gene expression of mammary lipogenic enzymes. J. Dairy Res. 69:521-531.

AOAC International. 2012. Official Methods of Analysis. 19th ed. AOAC International, Gaithersburg, MD.

Bauman, D. E., B. A. Corl, and D. G. Peterson. 2003. The biology of conjugated linoleic acids in ruminants. Pages 146-173 in Advances in Conjugated Linoleic Acid Research. Vol. 2. J.-L. Sébédio, W. W. Christie, and R. O. Adolf, ed. AOCS Press, Champaign, IL.

Baumgard, L. H., E. Matitashvili, B. A. Corl, D. A. Dwyer, and D. E. Bauman. 2002. trans-10, cis-12 conjugated linoleic acid decreases lipogenic rates and expression of genes involved in milk lipid synthesis in dairy cows. J. Dairy Sci. 85:2155-2163.

Bernard, L., C. Leroux, and Y. Chilliard. 2008. Expression and nutritional regulation of lipogenic genes in the ruminant lactating mammary gland. Adv. Exp. Med. Biol. 606:67-108.

Bernard, L., C. Leroux, and Y. Chilliard. 2013. Expression and nutritional regulation of stearoyl-CoA desaturase genes in the ruminant mammary gland: Relationship with milk fatty acid composition. Pages 161-193 in Stearoyl-CoA Desaturase Genes in Lipid Metabolism. P. D. J. M. Ntambi, ed. Springer, New York, NY.

Bichi, E., P. G. Toral, G. Hervás, P. Frutos, P. Gómez-Cortés, M. Juárez, and M. A. de la Fuente. 2012. Inhibition of $\Delta^{9}$-desaturase activity with sterculic acid: Effect on the endogenous synthesis of cis-9 18:1 and cis-9, trans-11 18:2 in dairy sheep. J. Dairy Sci. 95:5242-5252.

Boivin, M., R. Gervais, and P. Y. Chouinard. 2013. Effect of grain and forage fractions of corn silage on milk production and composition in dairy cows. Animal 7:245-254.

Brumby, P. E., J. E. Storry, and J. D. Sutton. 1972. Metabolism of codliver oil in relation to milk fat secretion. J. Dairy Res. 39:167-182.

CCAC (Canadian Council on Animal Care). 1993. Guide to the Care and Use of Experimental Animals. Vol. 1. E. D. Olfert, B. M. Cross, and A. A. McWilliam, ed. CCAC, Ottawa, ON, Canada.

Chilliard, Y., A. Ferlay, and M. Doreau. 2001. Effect of different types of forages, animal fat or marine oils in cow's diet on milk fat secretion and composition, especially conjugated linoleic acid (CLA) and polyunsaturated fatty acids. Livest. Prod. Sci. 70:31-48.

Chilliard, Y., A. Ferlay, R. Mansbridge, and M. Doreau. 2000. Ruminant milk fat plasticity: Nutritional control of saturated, polyunsaturated, trans and conjugated fatty acids. Ann. Zootech. 49:181-205.

Chouinard, P. Y., L. Corneau, D. E. Bauman, D. M. Barbano, and L. E. Metzger. 1999a. Conjugated linoleic acids alter milk fatty acid composition and inhibit milk fat secretion in dairy cows. J. Nutr. 129:1579-1584.

Chouinard, P. Y., L. Corneau, A. Sæbø, and D. E. Bauman. 1999b. Milk yield and composition during abomasal infusion of conjugated linoleic acids in dairy cows. J. Dairy Sci. 82:2737-2745.

Chouinard, P. Y., J. Lévesque, V. Girard, and G. J. Brisson. 1997 Dietary soybeans extruded at different temperatures: Milk composition and in situ fatty acid reactions. J. Dairy Sci. 80:2913-2924.

Cook, L. J., T. W. Scott, L. C. Mills, A. C. Fogerty, and A. R. Johnson. 1976. Effect of protected cyclopropene fatty acids on the composition of ruminant milk fat. Lipids 11:705-711.

Corl, B. A., L. H. Baumgard, D. A. Dwyer, J. M. Griinari, B. S. Phillips, and D. E. Bauman. 2001. The role of $\Delta^{9}$-desaturase in the production of cis-9, trans-11 CLA. J. Nutr. Biochem. 12:622-630.

de Veth, M. J., J. M. Griinari, A. M. Pfeiffer, and D. E. Bauman. 2004 Effect of CLA on milk fat synthesis in dairy cows: Comparison of inhibition by methyl esters and free fatty acids, and relationships among studies. Lipids 39:365-372.

Doreau, M., and A. Ferlay. 1994. Digestion and utilisation of fatty acids by ruminants. Anim. Feed Sci. Technol. 45:379-396.

Drackley, J. K., T. H. Klusmeyer, A. M. Trusk, and J. H. Clark. 1992. Infusion of long-chain fatty acids varying in saturation and chain length into the abomasum of lactating dairy cows. J. Dairy Sci. $75: 1517-1526$. 
Gervais, R., J. W. McFadden, A. J. Lengi, B. A. Corl, and P. Y. Chouinard. 2009. Effects of intravenous infusion of trans-10, cis-12 18:2 on mammary lipid metabolism in lactating dairy cows. J. Dairy Sci. 92:5167-5177.

Gervais, R., R. Spratt, M. Léonard, and P. Y. Chouinard. 2005. Lactation response of cows to different levels of ruminally inert conjugated linoleic acids under commercial conditions. Can. J. Anim. Sci. 85:231-242.

Glasser, F., P. Schmidely, D. Sauvant, and M. Doreau. 2008. Digestion of fatty acids in ruminants: A meta-analysis of flows and variation factors: 2. C18 fatty acids. Animal 2:691-704.

Gressley, T. F., S. M. Reynal, J. J. Olmos Colmenero, G. A. Broderick, and L. E. Armentano. 2006. Development of a tool to insert abomasal infusion lines into dairy cows. J. Dairy Sci. 89:3965-3967.

Griinari, J. M., B. A. Corl, S. H. Lacy, P. Y. Chouinard, K. V. V. Nurmela, and D. E. Bauman. 2000. Conjugated linoleic acid is synthesized endogenously in lactating dairy cows by $\Delta^{9}$-desaturase. J. Nutr. 130:2285-2291.

Hagemeister, H., D. Precht, and C. A. Barth. 1988. Studies on transfer of omega-3 fatty acids into bovine milk fat by dairy cows. Milchwissenschaft 43:153-158.

Hawke, J. C., and M. W. Taylor. 1983. Influence of nutritional factors on the yield, composition and physical properties of milk fat. Pages 37-81 in Developments in Dairy Chemistry - 2. Lipids. P. F. Fox, ed. Appl. Sci., New York, NY.

Hussein, M., K. H. Harvatine, W. M. P. B. Weerasinghe, L. A. Sinclair, and D. E. Bauman. 2013a. Conjugated linoleic acid-induced milk fat depression in lactating ewes is accompanied by reduced expression of mammary genes involved in lipid synthesis. J. Dairy Sci. 96:3825-3834.

Hussein, M., K. J. Harvatine, Y. R. Boisclair, and D. E. Bauman. 2013b. Supplementation with fish oil as a source of n-3 fatty acids does not downregulate mammary lipogenesis in lactating mice. J. Nutr. 143:1913-1919.

Jacobs, A. A. A., J. Dijkstra, W. H. Hendriks, J. van Baal, and A. M. van Vuuren. 2013. Comparison between stearoyl-CoA desaturase expression in milk somatic cells and in mammary tissue of lactating dairy cows. J. Anim. Physiol. Anim. Nutr. (Berl.) 97:353-362.

Jacobs, A. A. A., J. van Baal, M. A. Smits, H. Z. H. Taweel, W. H. Hendriks, A. M. van Vuuren, and J. Dijkstra. 2011. Effects of feeding rapeseed oil, soybean oil, or linseed oil on stearoyl-CoA desaturase expression in the mammary gland of dairy cows. J. Dairy Sci. 94:874-887.

Jeffcoat, R., and M. R. Pollard. 1977. Studies on the inhibition of the desaturases by cyclopropenoid fatty acids. Lipids 12:480-485.

Kay, J. K., T. R. Mackle, M. J. Auldist, N. A. Thomson, and D. E. Bauman. 2004. Endogenous synthesis of cis-9, trans-11 conjugated linoleic acid in dairy cows fed fresh pasture. J. Dairy Sci. 87:369-378.

Keating, A. F., J. J. Kennelly, and F. Zhao. 2006. Characterization and regulation of the bovine stearoyl-CoA desaturase gene promoter. Biochem. Biophys. Res. Commun. 344:233-240.

Kelsey, J. A., B. A. Corl, R. J. Collier, and D. E. Bauman. 2003. The effect of breed, parity, and stage of lactation on conjugated linoleic acid (CLA) in milk fat from dairy cows. J. Dairy Sci. 86:2588-2597.
Lengi, A. J., and B. A. Corl. 2007. Identification and characterization of a novel bovine stearoyl-CoA desaturase isoform with homology to human SCD5. Lipids 42:499-508.

Livak, K. J., and T. D. Schmittgen. 2001. Analysis of relative gene expression data using real-time quantitative PCR and the $2^{-\triangle \Delta C T}$ method. Methods 25:402-408.

Loor, J. J., M. Doreau, J. M. Chardigny, A. Ollier, J. L. Sebedio, and Y. Chilliard. 2005. Effects of ruminal or duodenal supply of fish oil on milk fat secretion and profiles of trans-fatty acids and conjugated linoleic acid isomers in dairy cows fed maize silage. Anim. Feed Sci. Technol. 119:227-246.

Mauvoisin, D., and C. Mounier. 2011. Hormonal and nutritional regulation of SCD1 gene expression. Biochimie 93:78-86.

Miyazaki, M., and J. M. Ntambi. 2003. Role of stearoyl-coenzyme A desaturase in lipid metabolism. Prostaglandins Leukot. Essent. Fatty Acids 68:113-121.

Mosley, E. E., and M. A. McGuire. 2007. Methodology for the in vivo measurement of the $\Delta^{9}$-desaturation of myristic, palmitic, and stearic acids in lactating dairy cattle. Lipids 42:939-945.

Nixon, J. E., T. A. Eisele, J. D. Hendricks, and R. O. Sinnhuber. 1977. Reproduction and lipid composition of rats fed cyclopropene fatty acids. J. Nutr. 107:574-583.

NRC. 2001. Nutrient Requirements for Dairy Cattle. 7th rev. ed. Natl. Acad. Sci., Washington, DC.

Ntambi, J. M., and M. Miyazaki. 2004. Regulation of stearoyl-CoA desaturases and role in metabolism. Prog. Lipid Res. 43:91-104.

Palmquist, D. L., and T. C. Jenkins. 1980. Fat in lactation rations: Review. J. Dairy Sci. 63:1-14.

Pennington, J. A., and C. L. Davis. 1975. Effects of intraruminal and intra-abomasal additions of cod-liver oil on milk fat production in the cow. J. Dairy Sci. 58:49-55.

Raju, P. K., and R. Reiser. 1967. Inhibition of fatty acyl desaturase by cyclopropene fatty acids. J. Biol. Chem. 242:379-384.

Rechsteiner, M., and S. W. Rogers. 1996. PEST sequences and regulation by proteolysis. Trends Biochem. Sci. 21:267-271.

Schauff, D. J., J. H. Clark, and J. K. Drackley. 1992. Effects of feeding lactating dairy cows diets containing extruded soybeans and calcium salts of long-chain fatty acids. J. Dairy Sci. 75:3003-3019.

Shingfield, K. J., and J. M. Griinari. 2007. Role of biohydrogenation intermediates in milk fat depression. Eur. J. Lipid Sci. Technol. 109:799-816.

Toral, P. G., L. Bernard, Y. Chilliard, and F. Glasser. 2013. Short communication: Diet-induced variations in milk fatty acid composition have minor effects on the estimated melting point of milk fat in cows, goats, and ewes: Insights from a meta-analysis. J. Dairy Sci. 96:1232-1236.

Undersander, D., D. R. Mertens, and N. Thiex. 1993. Forage Analyses Procedures. National Forage Testing Association, Omaha, NE.

Van Soest, P. J., J. B. Robertson, and B. A. Lewis. 1991. Methods for dietary fiber, neutral detergent fiber and nonstarch polysaccharides in relation to animal nutrition. J. Dairy Sci. 74:3583-3597.

Villeneuve, M.-P., Y. Lebeuf, R. Gervais, G. F. Tremblay, J. C. Vuillemard, J. Fortin, and P. Y. Chouinard. 2013. Milk volatile organic compounds and fatty acid profile in cows fed timothy as hay, pasture, or silage. J. Dairy Sci. 96:7181-7194. http://dx.doi. org/10.3168/jds.2013-6785. 